\begin{tabular}{lcccr} 
T H E & A R C H I V E & O F & M E C H A N I C A L & E N G I N E E R I N G \\
\hline VOL. LVII & 2010 & Number 1
\end{tabular}

Key words: turbulent slurry flow, particles-wall shear stress

\title{
INFLUENCE OF COARSE-DISPERSIVE SOLID PHASE ON THE 'PARTICLES-WALL' SHEAR STRESS IN TURBULENT SLURRY FLOW WITH HIGH SOLID CONCENTRATION
}

\begin{abstract}
The paper concerns simulation of fully developed and axially-symmetrical turbulent flow of coarse-dispersive slurry if all solid particles have similar size and shape with particles diameter from $1 \mathrm{~mm}$ to $5 \mathrm{~mm}$, solid density from $1045 \mathrm{~kg} / \mathrm{m}^{3}$ to $3000 \mathrm{~kg} / \mathrm{m}^{3}$, and solid concentration by volume from $20 \%$ to $40 \%$. The author examines the influence of particle diameter on additional shear stress due to the 'particles-wall' interactions for moderate and high solid concentration. The mathematical model was developed using Bagnold's concept, [26] and assumes that the total wall shear stresses are equal to the sum of 'liquid-wall' and 'particles-wall' shear stresses. The mathematical model was successfully verified with own measurements of frictional head loss in vertical coarse - dispersive slurry flow, named: 'sand-water', 'polystyrene-water' and 'pvc-water', [10], [26]. The mathematical model can predict 'particles-wall' shear stress, pressure drop and friction factor for coarse-dispersive turbulent slurry flow in a pipe, [10].

The aim of the paper is to present qualitative and quantitative dependence of solid particle diameter, solid particle density, solid concentration, and Reynolds number for carrier liquid phase on the 'particles-wall' shear stress. It is demonstrated that the solid particle diameter plays crucial role in its dependence on the 'particleswall' shear stress. It was proved that in particular flow conditions the 'particles-wall' shear stress is much higher compared to the carrier liquid wall shear stress.
\end{abstract}

\section{Introduction}

Solid-liquid flow is widely employed in industry and nature, and can be found in transports by pumps in various pipelines. Determining the most efficient and economical way out of pumping any solids in carrier liquid requires careful consideration and analysis of numerous factors, some of which can have a significant impact on performance and costs. Among them,

* Kielce University of Technology, Chair of Production Engineering, Al. Tysiaclecia P.P. 7, 25-314 Kielce, Poland; E-mail: artur.bartosik@tu.kielce.pl 
there is particle diameter, solid concentration, particle density, deposition velocity, and properly matched characteristics of the pipeline and the pump.

Enormous tonnages of solid-liquid mixtures, named as slurries, are pumped every hour in industry. The application of slurry flow, which involves the largest quantities, is the dredging industry. As a single dredge may be required to maintain a throughput of 7000 tones of slurry per hour, very large centrifugal pumps are used. For instance, phosphate matrix is recovered by huge draglines in open-pit mining operations in Florida where $30 \%$ of the world demand are produced. It is then slurred, and pumped to the wash plants through pipelines with a typical length of about $14 \mathrm{~km}$. Each year some 34 millions of tones of phosphate matrix are transported in this manner. This industry employs centrifugal pumps with impeller diameters up to $1.4 \mathrm{~m}$, whose drive capacity is often in excess of $1 \mathrm{MW}$. Many other types of open-pit mining use slurry transport, and the number of such applications is increasing, as it becomes clear that the slurry transport is more cost-effective than transport by rail, truck or conveyor belt, [1].

It is quite common that partially processed materials in several industries are often in a slurry form, facilitating pump-pipeline transportation. As an example, Black Mesa pipeline transports partially-processed coal slurry from the mine to a power plant more than $430 \mathrm{~km}$ distance. Horizontal pipe diameter is $0.457 \mathrm{~m}$ while a downward pipe diameter is $0.254 \mathrm{~m}$. Recent decades have seen a great increase in the transport of waste materials, in slurry form, to suitable deposit sites.

Solid-liquid transportation usually faces various problems like, for instance, abrasion of the pump elements, especially between the rotating impeller and the stationary throat bush, the rotating shaft sleeve and the stationary packing, inlet, and outlet ducts. Because of abrasive characteristics of the solid particles of sand or gravel, the pumps and pipelines suffer during the work under these conditions. The power, capacity, resistance to wear and breakdown and robustness, are the essential keys of efficient pump dredging. The characteristics of dredging pumps and pipelines require a long working life in abrasive conditions, a limited influence of wear on pump performance, and a low net positive suction head requirement. The abrasion in pump or in pipeline can be defined by the loss of weight per unit area or loss in thickness under dynamic action of solid particles acting on the solid wall, [2]. In this process the 'particles - wall' interaction, especially at the high flow rate, and high solid concentration play crucial role and research on determination of the 'particles-wall' stress is much desired.

Slurries can be broadly divided into two general groups of non-settling or settling types. Non-settling slurries contain very fine particles which can form stable homogeneous mixtures exhibiting increased apparent viscosity 
and in some cases turbulence damping, [3], [4]. These slurries usually have low abrasive characteristics and usually exhibit non - Newtonian behavior and the yield stress. Settling slurries are formed by coarse particles and tend to have higher abrasive properties. When someone predicts the frictional head loss of slurry flow with coarse particles, it is reasonable to assume the Newtonian model, as now one can measure rheology in such slurries, [2]. Solid-liquid flow models are classified according to the solid phase distribution in the carrier liquid. The basic flow patterns observed in slurries of coarse particles are: stationary bed, moving bed, heterogeneous flow, and pseudo-homogeneous flow, [2], [5] and [6]. It has been the endeavor of researchers around the world to develop accurate models for pressure drop and concentration distribution in slurry pipelines. Pressure drop is one of the most important technical parameters to be evaluated by the designers for designing a pipeline slurry transportation system, and the parameter which dictates the selection of pump capacity. Several studies for pressure drop prediction in slurry flow are available in literature, [7] to [14].

In reference to experiments on interaction of coarse-dispersive phase in a solid-liquid flow, one should mention basic research of Bagnold, [15]. Bagnold conducted measurements on highly concentrated Couette flow for neutrally buoyant wax spheres of $1.32 \mathrm{~mm}$ diameter in a concentric cylinder apparatus, the outer cylinder of which was driven with inner diameter of $114 \mathrm{~mm}$, and gap width of $10.8 \mathrm{~mm}$. Bagnold measured rotational velocities, total shear stress (liquid and particles) and normal stress (particles stress). The viscosity of the employed fluids was 0.001 and $0.007 \mathrm{~Pa} \cdot \mathrm{s}$, and the density was equal to water density. Volumetric solid concentrations were in the range of $13<\mathrm{C}_{V}<62 \%$. On the basis of measurements, Bagnold proposed the expression of solid-solid shear stress, [15].

Solid concentration distribution and modification of turbulence by solid particles has been investigated experimentally by several researchers. The structure of particle diameter influence on solid concentration distribution was widely measured by Nasr-El-Din et al., [16], Sumner et al., [17], and Eskin and Miller, [18], while turbulence in the near wall region was examined by Kuboi et al., [19], Schreck and Kleis, [20], Nouri and Whitelaw, [21], Chen and Kadambi, [22], for maximum possible solid concentration by volume equal to $25 \%$. It was shown that ejection-sweep cycle is affected strongly by particles and slip velocity decreases with solid concentration increase. A review of experimental studies on turbulence modification by particles is given by Gore and Crowe, [23]. The authors showed that the ratio of particle diameter and turbulence length scale is an appropriate measure to decide if turbulence intensity of carrier fluid is enhanced or attenuated by dispersed particles. However, the data are scattered and indication about 
the degree of increase or decrease versus flow condition are not provided. Besides, these data are for solid-air flow only. Broadly speaking someone can say that, if the solid particles are sufficiently small, their relaxation time is low, and they can follow the carrier fluid. In such a case, the diffusion process distribute particles uniformly across the stream. When coarse particles are considered, their relaxation time is high and additional swirls or wakes appears causing the level of turbulence to be increased. Other quite similar flows reveal almost no turbulence modification up to fairly high mass loading ratios, [24]. Turbulence attenuation or generation can have enormous effects on device performance, yet there is no theory or model that allows consistently accurate predictions of turbulence modification. The physical mechanisms are also so poorly understood that experts in the field cannot predict if turbulence attenuation or generation will occur in a given flow. Therefore, the phenomenological models of slurry flow with coarse particles are still desirable especially if they take into account the 'particles-wall' stress.

Sundaresan et al., [25], outlined a number of scientific challenges which represent building blocks for the comprehensive understanding of disperse flows encountered in a variety of technologies and in nature. They concluded that new experiments and/or analyses are needed to cast light on the important phenomena that cause turbulence attenuation or generation. The authors suggested that the experiments should be conducted in simple turbulent flows such as grid turbulence, fully developed pipe or channel flow, or simple axisymmetrical flows. Regardless of geometry, experiments must include a wide range of particle parameters in a single fixed facility.

As mentioned above, in the case of a solid-liquid flow with coarse particles the 'particles-wall' interaction plays important role in prediction of pressure drop and abrasive process. Therefore, the paper deals with simulation of fully developed axially symmetrical turbulent pipe flow of coarse-dispersive slurries. The carrier liquid is water, and all the solid particles are monodispersive and have similar size and shape with diameter from 1 to $5 \mathrm{~mm}$, solids density from $1045 \mathrm{~kg} / \mathrm{m}^{3}$ to $3000 \mathrm{~kg} / \mathrm{m}^{3}$, and solid concentration by volume from $20 \%$ to $40 \%$. The main aim of the paper is to examine influence of the coarse-dispersive particles on the 'particles-wall' shear stress for moderate and high solid concentration.

\section{Mathematical model}

In order to develop mathematical model for pseudo-homogeneous flow of coarse-dispersive slurry with moderate and high solid concentration, Shook and Bartosik, [26] re-evaluated original Couette flow data of Bagnold, [15]. 
They assumed that the flowing solid particles, submerged in water, are mono dispersive with solid particles density, diameter and concentration equal to: $1045 \leq \rho_{P} \leq 2650 \mathrm{~kg} / \mathrm{m}^{3}, 1.3 \leq \mathrm{d}_{P} \leq 3.4 \mathrm{~mm}$ and $\mathrm{C}_{V}=(10-50) \%$, respectively, [26]. Their mathematical model was improved by using modified empirical function in the equation for the 'particles-wall' shear stress, [10]. The presented mathematical model assumes that the coarse-dispersive slurry is flowing in the vertical smooth pipe with constant diameter in upward 'ox' direction, and is turbulent, stationary, fully developed, axially symmetrical, isothermal and without circumferential eddies. As a result of high inertia forces in the slurry flow, the buoyancy and gravitational forces acting on flowing particles are neglected and the only dominant shear stresses acting on the pipe wall are 'liquid-wall' and 'particles-wall' stresses. Then, the total shear stress is modeled as a superposition of the liquid and the inertial particles stresses.

As mentioned above, only small solid particles suspended in the slurry are responsible for non-Newtonian behavior. Then, when slurry flows with coarse solid particles are considered, it is reasonable to assume the Newtonian fluid model. For the Newtonian liquid of constant density and viscosity the general form of Navier-Stokes equation in Cartesian coordinates for vertical upward flow can be written as follows, [2]:

$$
\rho\left(\frac{\partial \vec{U}}{\partial t}+\vec{U} \cdot \nabla \vec{U}\right)=-\nabla p-\rho g \nabla h+\mu \nabla^{2} \vec{U}
$$

Taking into account the assumptions that the flow is axially symmetrical $(\mathrm{V}=0)$ and without circumferential eddies $(\mathrm{W}=0)$, the linear momentum equation for quantities averaged over a pipe cross section can be expressed for ox-direction as follows, [27]:

$$
\rho\left(\frac{\partial U_{S}}{\partial t}+U_{S} \frac{\partial U_{S}}{\partial x}+g \frac{\partial h}{\partial x}\right)+\frac{\partial p}{\partial x}+4 \frac{\tau_{w}}{D}=0
$$

since the only component of velocity vector is velocity in the main flow direction 'ox', denoted as $\mathrm{U}=\mathrm{f}(\mathrm{y})$.

The velocity averaged over a pipe cross section $\mathrm{U}_{S}$, appearing in equation (2), is computed by integration of the local velocity $U$ in the main flow direction 'ox', which varies in 'oy' direction, as follows:

$$
U_{S}=\frac{1}{A} \iint_{A} U d A
$$

where $\mathrm{A}$ is a pipe cross section and is constant. 
The resisting wall shear stress $\tau_{w}$, which appears in equation (2), is the consequence of the viscous forces in equation (1), which act on the inner pipe surface of $\Delta \mathrm{x}$ length. Taking into account stationary $(\partial / \partial \mathrm{t}=0)$ and fully developed flow $\left(\partial \mathrm{U}_{S} / \partial \mathrm{x}=0\right)$ one can write:

$$
\rho g \frac{\Delta h}{\Delta x}+\frac{\Delta p}{\Delta x}+\frac{4}{D} \tau_{w}=0
$$

The first term in equation (4) is called the gravitational term and is denoted as:

$$
\frac{\Delta p^{*}}{\Delta x}=\rho g \frac{\Delta h}{\Delta x}
$$

The gravitational term is equal to zero for horizontal flow and its importance increases with increase of pipe inclination.

Taking into account equation (4) and (5), the final form of equation for pressure drops in vertical upward slurry flow is as follows:

$$
\frac{p_{1}-p_{2}}{\Delta x}=\frac{\Delta p^{*}}{\Delta x}+\frac{4}{D} \tau_{w}
$$

where $\mathrm{p}_{1}-\mathrm{p}_{2}$ is the total static pressure drop in vertical up-ward pipe flow.

It is useful, however, to convert experimental data for vertical flow into data for horizontal flow in order to compare results of the slurry flow with the carrier liquid phase flow. In order to express the pressure drop for horizontal pipe flow, using data for vertical flow, the term $\Delta \mathrm{p}^{*}$ must be subtracted from the total pressure drop. In such a case, we can write that:

$$
\frac{\left(p_{1}-p_{2}\right)-\Delta p^{*}}{\Delta x}=\frac{4}{D} \tau_{w}
$$

where the term at the left hand side of equation (7) is the pressure drop for the horizontal pipe flow.

Taking into account Fig. 1, which presents measurements of the total pressure drop in vertical slurry flow, we can calculate the gravitational term $\Delta \mathrm{p}^{*} / \Delta \mathrm{x}$. Assuming that the solid particles are uniformly distributed between chosen pipe test sections 1-1 and 2-2 (the distance during the measurements was $\Delta \mathrm{x}=2.277 \mathrm{~m}$ ), the equilibrium equation (for $\mathrm{U}_{S}=0$ ) can be expressed as:

$$
p_{2}+\rho_{m} g \Delta x+\rho_{L} g h=p_{2}+\rho_{L} g(\Delta x+h)+\Delta p^{*}
$$

Then, the gravitational term can be expressed as:

$$
\Delta p^{*}=g \Delta x\left(\rho_{m}-\rho_{L}\right)
$$

and finally: 


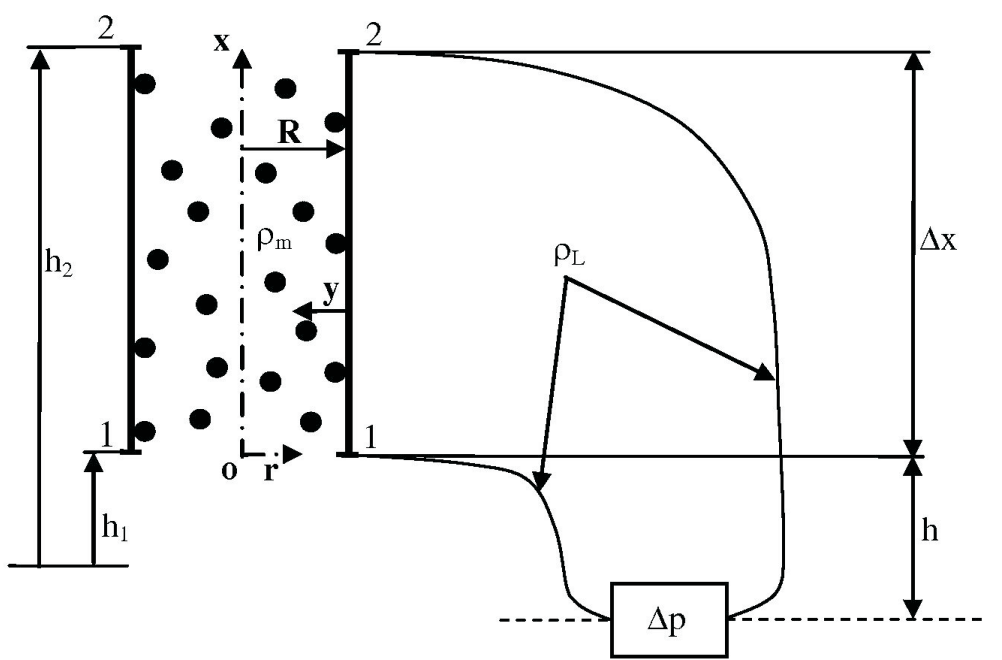

Fig. 1. Measurements of the total pressure drop in the vertical upward slurry flow

$$
\frac{\Delta p^{*}}{\Delta x}=g\left(\rho_{m}-\rho_{L}\right)
$$

The gravitational term, calculated by (10), was subtracted from the measured total pressure drop over the vertical test sections for each set of data at $\mathrm{C}_{V}=10,20,30,40,45$ and $50 \%$ presented in Chapter 3 and 4. The slurry density, which appears in equations (8)-(10), can be calculated using solid concentration as:

$$
\rho_{m}=\rho_{L}\left[1+C_{V}(S-1)\right]
$$

Then, after subtracting aforementioned gravitational term, the equation (7) for horizontal slurry flow can be written as:

$$
i_{m} \rho_{L} g=\frac{4}{D}\left(\tau_{L}+\tau_{P}\right)
$$

where the slurry frictional head loss $i_{m}$ is expressed in [m water / $\mathrm{m}$ pipe].

Bagnold, [15], interpreted the torque measurements by assuming that the total wall shear stress $\tau_{w}$ is the sum of the liquid $\tau_{L}$ and the particles $\tau_{P}$ stresses:

$$
\tau_{w}=\tau_{L}+\tau_{P}
$$

where

$$
\tau_{L}=\mu_{L} \frac{d U}{d y}=i_{L} \rho_{L} g \frac{D}{4}
$$


In accordance with Bagnold's approach, the particle stress can be expressed by the following relationship, [15]:

$$
\tau_{P}=K \rho_{P} d_{P}^{2} \beta^{2}\left(\frac{d U}{d y}\right)^{2}
$$

where $\mathrm{K}$ is proportionality coefficient equal to 0.013 and $\beta$ is the linear solid concentration (particle diameter / shortest distance between particles), defined as, [15]:

$$
\beta=\frac{1}{\left(\frac{C_{\max }}{C}\right)^{1 / 3}-1}
$$

where $\mathrm{C}_{\max }$ is maximum possible static concentration by volume of solids in a pipe, and $\mathrm{C}$ is a local volumetric concentration of solids.

Bagnold suggested that equation (15) is valid for values of the dimensionless number (Bagnold number):

$$
N_{B}=\rho_{P} \beta^{0.5} d_{P}^{2} \frac{d U}{d y} \frac{1}{\mu_{L}}
$$

greater than 450, what is always true in the case of turbulent flow.

Taking into account equation (6) and Bagnold's equations (15) and (16), with the aim to predict the pressure drop for the coarse-dispersive turbulent slurry flow in the vertical pipe, does not give satisfactory results. The analysis indicates that the $\mathrm{K}$ is not a coefficient as Bagnold suggested, [14] but it is a function of liquid Reynolds number [10], [26]. Taking into account Bagnold's concept, Shook and Bartosik [26] developed a mathematical model, in which instead of $\mathrm{K}$ coefficient the $\mathrm{A}_{B}$ function was introduced. Using Bagnold's equation (15) and introducing $A_{B}$ function instead of proportionality coefficient K, Shook and Bartosik, [26] expressed equation (12) as follows:

$$
i_{m} \rho_{L} g=\frac{4}{D}\left[\frac{D}{4} i_{L} \rho_{L} g+A_{B} \rho_{P} d_{P}^{2} \beta_{S}^{2}\left(\frac{d U}{d y}\right)^{2}\right]
$$

The dimensionless solid concentration $\beta_{S}$ that appeared in equation (18), was defined by Shook and Bartosik, [26], in more practical way by using volume fraction of solids averaged in cross section, as:

$$
\beta_{S}=\frac{1}{\left(\frac{C_{\max }}{C_{V}}\right)^{1 / 3}-1}
$$

where $\mathrm{C}_{V}$ is solids concentration averaged across the pipe. 
If the experimental relations $\mathrm{i}_{m}=\mathrm{f}\left(\mathrm{U}_{S}\right)$ and $\mathrm{i}_{L}=\mathrm{f}\left(\mathrm{U}_{S}\right)$ are known, it is possible to determine unknown function $\mathrm{A}_{B}$ as follows:

$$
A_{B}=\frac{D \rho_{L} g\left(i_{m}-i_{L}\right)}{4 \rho_{P} d_{P}^{2} \beta_{S}^{2}\left(\frac{d U}{d y}\right)^{2}}
$$

The shear rate appearing in equation (20) was designated for carrier liquid phase using Newtonian hypothesis as:

$$
\frac{d U}{d y}=\frac{\tau_{L}}{\mu_{L}}=i_{L} \rho_{L} g \frac{D}{4 \mu_{L}}
$$

The function $\mathrm{A}_{B}$ was designated on the basis of measurements of relationship $\mathrm{i}_{m}=\mathrm{f}\left(\mathrm{U}_{S}\right)$ and $\mathrm{i}_{L}=\mathrm{f}\left(\mathrm{U}_{S}\right)$ for solid particles $\mathrm{d}_{P}=1.3,1.5,2.8$ and 3.4 $\mathrm{mm}$, solid density $\rho_{P}=1045,1400$ and $2650 \mathrm{~kg} / \mathrm{m}^{3}$, and solid concentration $\mathrm{C}_{V}=(10-50) \%$, and for few pipe diameters. The best correlation is achieved if the $A_{B}$ function depends on the Reynolds number for carrier liquid phase. Experiments showed that the $A_{B}$ function differs for different pipe diameters and varies with the square of pipe diameter. For that reason, the relationship $\mathrm{B}_{B}=\mathrm{A}_{B} / \mathrm{D}^{2}=\mathrm{f}\left(\operatorname{Re}_{L}\right)$ was found experimentally in order to obtain smooth correlation for different pipe diameters. An improved version of the $\mathrm{B}_{B}$ function, and the 'particles-wall' shear stress, and relation for $i_{m}$ was proposed by Bartosik, [10]. Final version of the $\mathrm{B}_{B}$ function, which gives the best correlation, is presented in this paper and is described by equation (22).

- empirical function:

$$
B_{B}=\frac{A_{B}}{D^{2}}=8.254 \cdot 10^{7} \operatorname{Re}_{L}^{-2.316}
$$

in which the Reynolds number for carrier liquid phase is:

$$
R e_{L}=\frac{\rho_{L} U_{S} D}{\mu_{L}}
$$

-'particles-wall' shear stress:

$$
\tau_{P}=A_{B} \rho_{P} d_{P}^{2} \beta_{S}^{3 / 2}\left(\frac{d U}{d y}\right)^{2}=A_{B} \rho_{P} d_{P}^{2} \beta_{S}^{3 / 2} i_{L}^{2} \rho_{L}^{2} g^{2} \frac{D^{2}}{16 \mu_{L}^{2}}
$$

It was found, however, that dimensionless solid concentration $\beta_{S}$ should be in power of 3/2, instead of 2 as Bagnold suggested, [10].

- slurry frictional head loss: 


$$
i_{m}=i_{L}\left(1+\left(B_{B} D^{2}\right) \rho_{P} d_{P}^{2} \beta_{S}^{3 / 2} \frac{D}{4 \mu_{L}^{2}} i_{L} \rho_{L} g\right)
$$

The slurry friction factor can be developed using equations (12) and (11) as follows:

$$
\lambda_{m}=\frac{8 \tau_{w}}{\rho_{m} U_{S}^{2}}=\frac{2 i_{m} \rho_{L} g D}{\rho_{m} U_{S}^{2}}=\frac{2 i_{m} \rho_{L} g D}{\rho_{L}\left[1+C_{V}(S-1) U_{S}^{2}\right]}
$$

Finally, the mathematical model which consists of equations (22)-(26) together with (6) for vertical flow and (7) for horizontal flow, can predict the particles wall shear stress, pressure drop (or frictional head loss), and friction factor for fully developed and axially symmetrical turbulent flow of coarse-dispersive slurries. The mathematical model is dedicated for slurries with narrowly sized particles of diameter higher than $1.5 \mathrm{~mm}$.

\section{Experiments and mathematical model verification}

In order to verify the mathematical model, the measurements of $i_{m}=f\left(U_{S}\right)$ and $\mathrm{i}_{L}=\mathrm{f}\left(\mathrm{U}_{S}\right)$ were made in vertical closed loop of pipeline in up-ward flow. Slurries were prepared by adding weighted quantities of solids. A doublepipe heat exchanger allowed the temperature to be controlled to within $\pm 1 \mathrm{~K}$, to minimize the possibility of air being released from the solution to change the slurry density. Averaged slurry temperature was $\mathrm{T}=298 \mathrm{~K}$. Bulk velocities were measured with a magnetic flux flow meter whose calibration had been verified by volumetric flow measurements. Flow meter output voltages were converted to current and thence to an amplified (0-10) V signal which could be read with a computer. Pressure drop over the vertical test sections was measured with calibrated variable reluctance transducer (Validyne Model DP-15), whose demodulated signal output was read with a computer, [26].

Experiments were done for solid particles $\mathrm{d}_{P}=1.3,1.5,2.8$ and $3.4 \mathrm{~mm}$, solid density $\rho_{P}=1045,1400$ and $2650 \mathrm{~kg} / \mathrm{m}^{3}$, and solid concentration $\mathrm{C}_{V}=10$, 20, 30, 40, 45 and $50 \%$, and for few pipe diameters. Measurements for the vertical slurry flow were presented by Shook and Bartosik, [26] and Bartosik [10], while the measurements converted to the horizontal flow are presented by Bartosik [29] and in this paper for chosen pipe diameter $\mathrm{D}=0.026 \mathrm{~m}$. As mentioned above, if turbulence damping appears in a vertical slurry flow, it is suitable to convert the frictional head loss to the horizontal flow in order to compare the results of the slurry flow with the carrier liquid phase flow.

Fig. 2 presents measurements of $\mathrm{i}_{m}=\mathrm{f}\left(\mathrm{U}_{S}\right)$ for solid-liquid flow of polystyrene and water. The particle diameter is $\mathrm{d}_{P}=1.5 \mathrm{~mm}$ and particle 


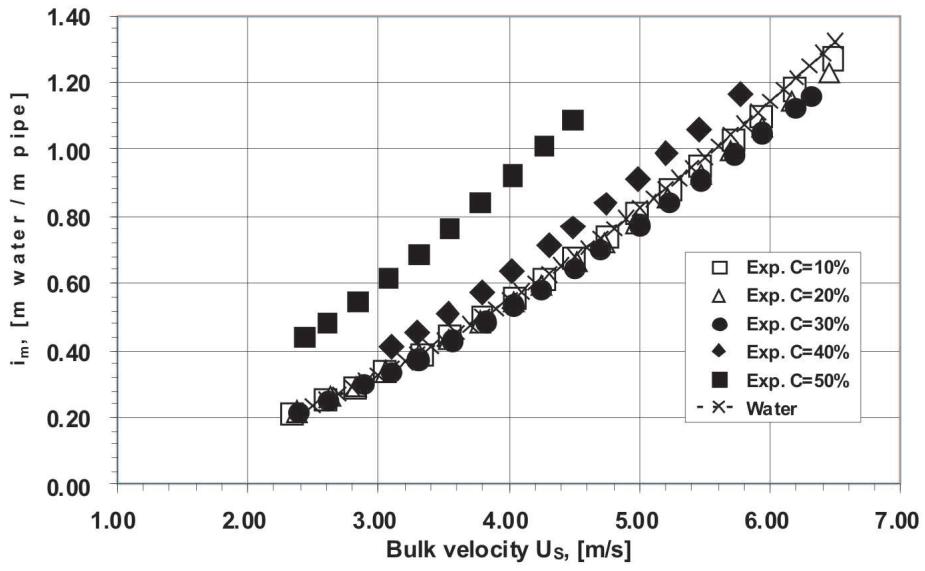

Fig. 2. Dependence of bulk velocity on 'polystyrene-water' frictional head loss for different solid concentration, $\mathrm{d}_{P}=1.5 \mathrm{~mm}, \rho_{P}=1045 \mathrm{~kg} / \mathrm{m}^{3}$

density $\rho_{P}=1045 \mathrm{~kg} / \mathrm{m}^{3}$. If solid concentration varies from $10 \%$ to $30 \%$, the frictional head loss is below the values for the water flow. In this case, turbulence damping in the slurry flow appears.

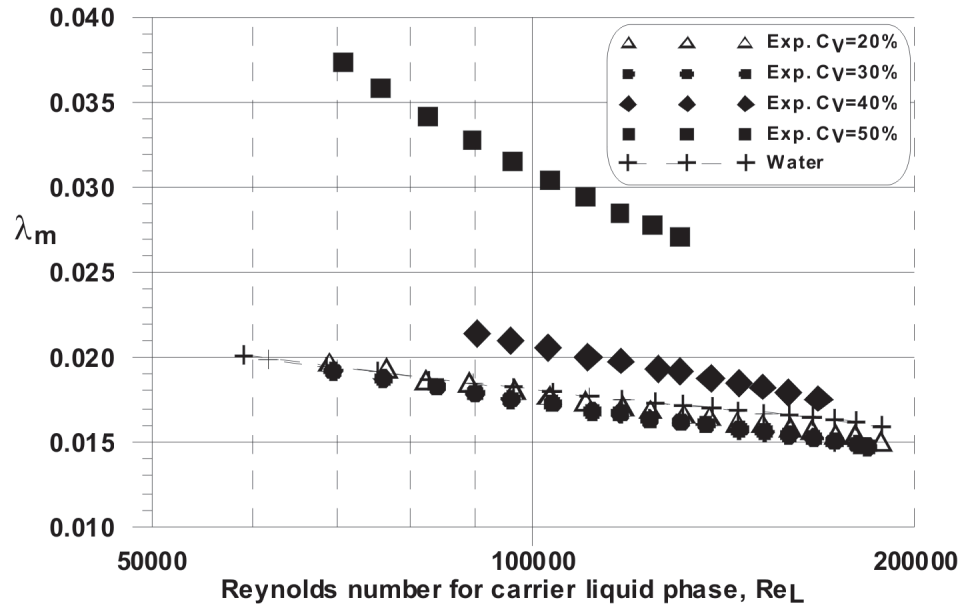

Fig. 3. Dependence of Reynolds number on 'polystyrene-water' friction factor for different solid concentration, $\mathrm{d}_{P}=1.5 \mathrm{~mm}, \rho_{P}=1045 \mathrm{~kg} / \mathrm{m}^{3}$

Fig. 3 confirms that for solid concentrations equal or below $30 \%$ by volume, the friction factor is smaller than for water flow. If solid concentration exceeds $50 \%$ by volume, there is almost double increase in the friction factor.

If particle diameter increases, the importance of turbulence damping decreases. This is confirmed in Fig. 4, which presents measurements of 'polystyrene-water' slurry flow for $\mathrm{d}_{P}=2.8 \mathrm{~mm}$ and $\rho_{P}=1045 \mathrm{~kg} / \mathrm{m}^{3}$. If solid 


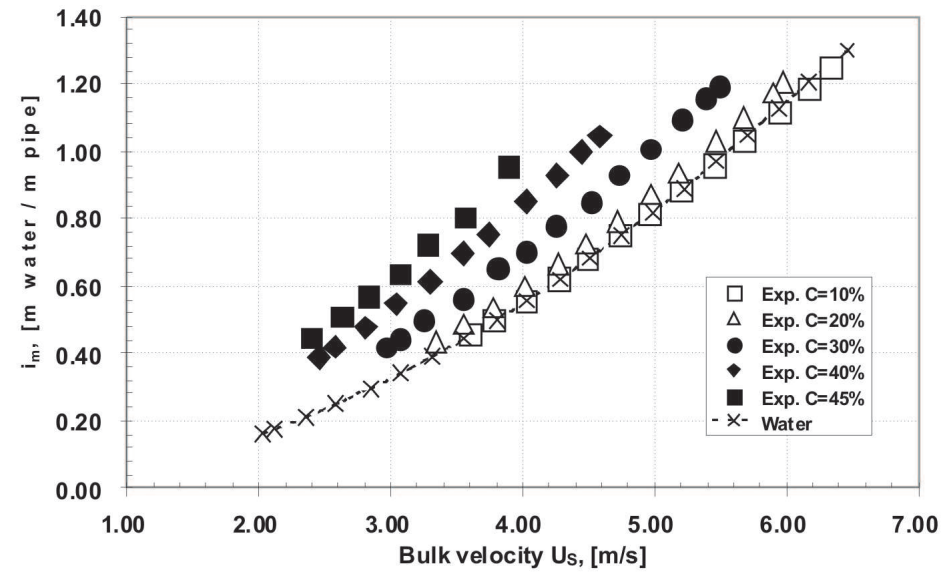

Fig. 4. Dependence of bulk velocity on 'polystyrene-water' frictional head loss for different solid concentration, $\mathrm{d}_{P}=2.8 \mathrm{~mm}, \rho_{P}=1045 \mathrm{~kg} / \mathrm{m}^{3}$

concentration is $10 \%$ by volume, the measured frictional head loss is similar to the one for water flow. If solid concentration increases, the measured $i_{m}$ values increase substantially, and are higher compared to slurry flow with $\mathrm{d}_{P}=1.5 \mathrm{~mm}$, which is clearly seen by comparing Fig. 2 and Fig. 4 . It should be emphasized, however, that for 'polystyrene-water' flow with $\mathrm{d}_{P}=2.8 \mathrm{~mm}$, maximum possible solid concentration in the experiments was $45 \%$ by volume.

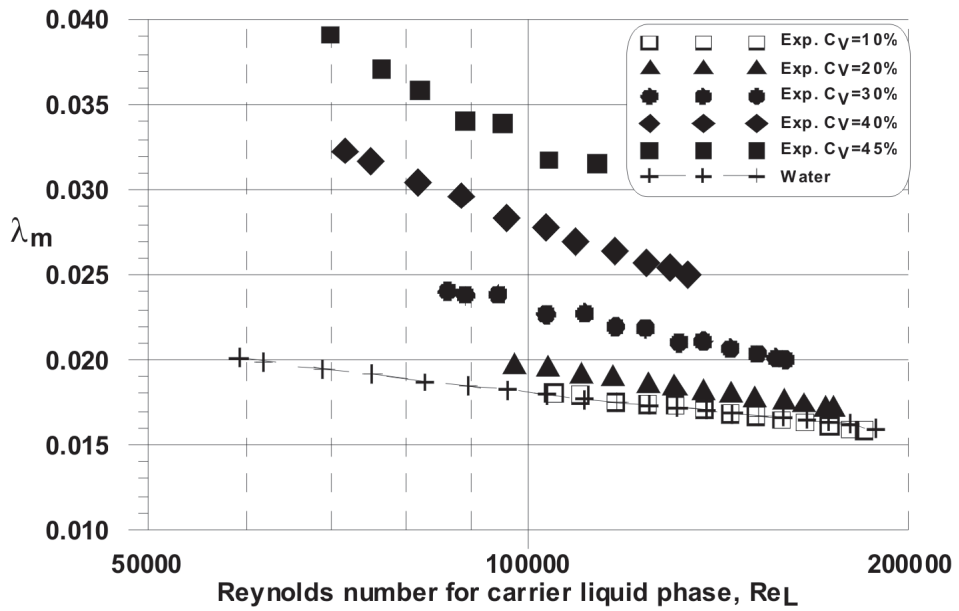

Fig. 5. Dependence of Reynolds number on 'polystyrene-water' friction factor for different solid concentration, $\mathrm{d}_{P}=2.8 \mathrm{~mm}, \rho_{P}=1045 \mathrm{~kg} / \mathrm{m}^{3}$

For the 'polystyrene-water' flow with particles diameter $\mathrm{d}_{P}=2.8 \mathrm{~mm}$ and solid concentration $10 \%$ by volume, the friction factor is similar to the one 
for water flow - Fig. 5. If solid concentration is higher than $10 \%$, the friction factor significantly differs from that for the water flow, and is increasing with solid concentration increase. Concluding, one can say that the friction factor is substantially higher for the slurry flow with particles diameter $\mathrm{d}_{P}=2.8 \mathrm{~mm}$ compared to the slurry flow with $\mathrm{d}_{P}=1.5 \mathrm{~mm}$.

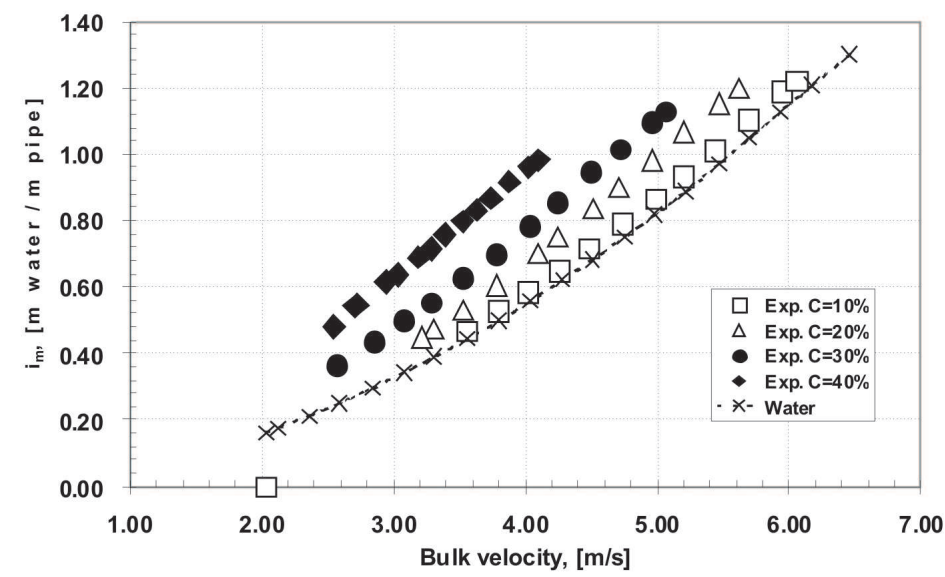

Fig. 6. Dependence of Reynolds number on 'pvc-water' frictional head loss for different solid concentration, $\mathrm{d}_{P}=3.4 \mathrm{~mm}, \rho_{P}=1400 \mathrm{~kg} / \mathrm{m}^{3}$

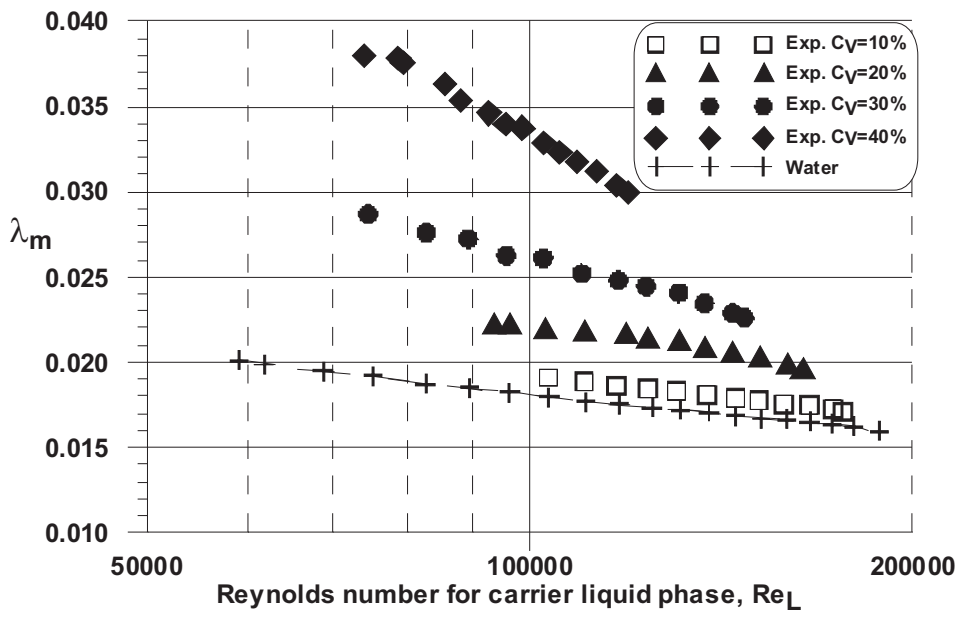

Fig. 7. Dependence of Reynolds number on 'pvc-water' friction factor for different solid concentration, $\mathrm{d}_{P}=3.4 \mathrm{~mm}, \rho_{P}=1400 \mathrm{~kg} / \mathrm{m}^{3}$

If the slurry flow of 'pvc-water' is considered, the particle diameter and solid density are higher compared to 'polystyrene-water' flow and are $\mathrm{d}_{P}=3.4 \mathrm{~mm}$ and $\rho_{P}=1400 \mathrm{~kg} / \mathrm{m}^{3}$ respectively. In such a case, the slurry fric- 
tional head loss is significantly higher than for water flow for all solid concentrations and increases with solid concentration increase - Fig. 6. The same applies to the friction factor, which is presented in Fig. 7. However, maximum possible solid concentration in the experiment was $40 \%$ by volume.
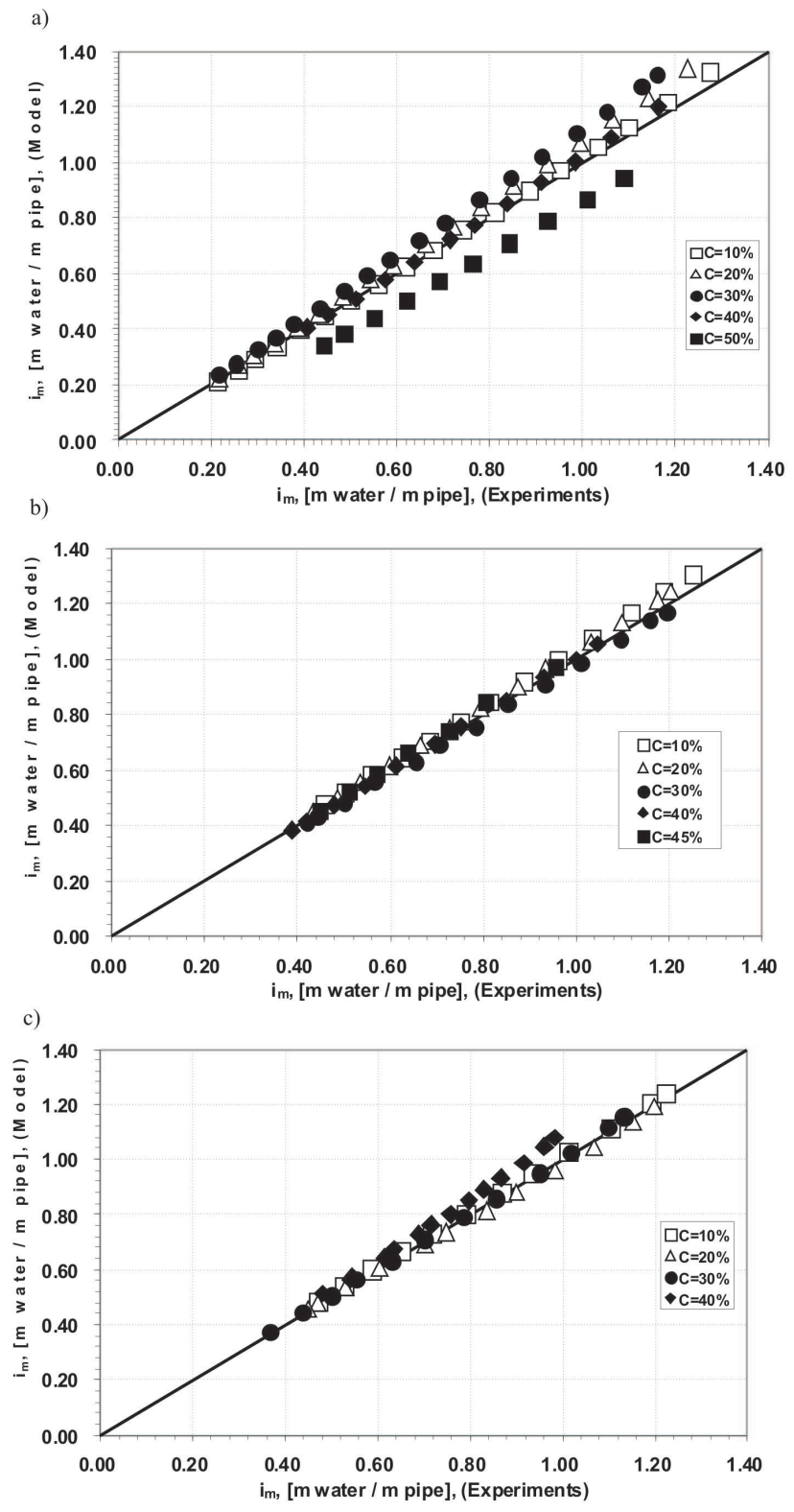

Fig. 8. Predicted frictional head loss versus experiments for: a) 'polystyrene-water' flow, $\mathrm{d}_{P}=1.5 \mathrm{~mm}, \rho_{P}=1045 \mathrm{~kg} / \mathrm{m}^{3} ; \mathrm{b}$ ) 'polystyrene-water' flow, $\mathrm{d}_{P}=2.8 \mathrm{~mm}, \rho_{P}=1045 \mathrm{~kg} / \mathrm{m}^{3}$;

c) 'pvc-water' flow, $\mathrm{d}_{P}=3.4 \mathrm{~mm}, \rho_{P}=1400 \mathrm{~kg} / \mathrm{m}^{3}$ 
For all aforementioned slurries, like 'polystyrene-water' with particles diameter $\mathrm{d}_{P}=1.5$ and $2.8 \mathrm{~mm}$ and 'pvc-water' with $\mathrm{d}_{P}=3.4 \mathrm{~mm}$, the measurements of the frictional head loss were compared with predictions using equation (25) and are presented in Fig. 8a, b, c, respectively. The comparison of predicted and measured frictional head loss, presented in Fig. 8a, b, c, shows that the highest discrepancy exists for 'polystyrene-water' with particles diameter $\mathrm{d}_{P}=1.5 \mathrm{~mm}$. In this case, the mathematical model overestimates the frictional head loss for solid concentration below or equal to $30 \%$, while for $\mathrm{C}_{V}=50 \%$ it underestimates this loss. In this case, the maximum relative error of predicted $i_{m}$ various from $-20 \%$ to $+14 \%$. The model overestimates the frictional head loss for solid concentration below or equal to $30 \%$ because damping of turbulence appears, as was shown in Fig. 2 and Fig. 3. If 'pvcwater' and 'polystyrene-water' slurries with particles diameter $\mathrm{d}_{P}=3.4$ and $2.8 \mathrm{~mm}$ are considered, the predicted and measured relationship of $\mathrm{i}_{m}=\mathrm{f}\left(\mathrm{U}_{S}\right)$ are matching well. The term $i_{m}-i_{L}$, is called the 'solids effect' and its importance rises with particle diameter increase.

The aforementioned mathematical model was examined by Matousek [28]. Matousek's experiments were carried out in a $150 \mathrm{~mm}$ vertical pipe for 'sand-water' flow at $\mathrm{C}_{V}=12,26,35$ and $43 \%$. All solid particles used in experiments were narrowly sized with particles diameter $\mathrm{d}_{P}=0.12$ and 0.37 $\mathrm{mm}$. They have shown that Bartosik-Shook model predicts smaller value of the solids effect than that measured in the vertical pipe flow. This is not surprising, however, as Bartosik-Shook model is dedicated for slurries with $\mathrm{d}_{P}>1.5 \mathrm{~mm}$.

\section{Influence of coarse particles on the 'particles-wall' stress}

For the purpose of this paper, the equation (24) will be used in order to predict coarse particles influence on the 'particles-wall' shear stress in slurry flow for moderate and high solid concentration. The range of investigated parameters is shown in Table 1.

Table 1.

The range of studied parameters for simulation of the 'particles-wall' stress

\begin{tabular}{|c|c|c|c|c|c|c|}
\hline $\mathrm{d}_{P}$ & $\rho_{P}$ & $\mathrm{C}_{V}$ & $\mathrm{D}$ & $\mathrm{C}_{\max }$ & $\mathrm{U}_{S}$ & $\mathrm{Re}_{L}$ \\
\hline$[\mathrm{mm}]$ & {$\left[\mathrm{kg} / \mathrm{m}^{3}\right]$} & {$[\%]$} & {$[\mathrm{m}]$} & {$[\%]$} & {$[\mathrm{m} / \mathrm{s}]$} & {$[-]$} \\
\hline $1-5$ & $1045-3000$ & $20-40$ & 0.026 & 64 & $2.5-6.5$ & $72800-189400$ \\
\hline
\end{tabular}

In accordance with the mathematical model, the 'particles-wall' shear stress $\left(\tau_{P}\right)$ depends on several parameters, like particle diameter, particle density, solid concentration, strain rate, maximum possible static solid con- 
centration, and Reynolds number for carrier liquid phase. Figs. 9a-9c present dependence of the Reynolds number for carrier liquid phase on the 'particleswall' shear stress $\left(\tau_{P}\right)$ for various values of particles diameter $\mathrm{d}_{P}=1,2,3$, 4 and $5 \mathrm{~mm}$, solid concentration $\mathrm{C}_{V}=20,30$ and $40 \%$, and for chosen solid density $\rho_{P}=1045 \mathrm{~kg} / \mathrm{m}^{3}$ and for constant pipe diameter $\mathrm{D}=0.026 \mathrm{~m}$. It is evident that for slurry flow with particle diameter $\mathrm{d}_{P}=1 \mathrm{~mm}$ the 'particles-wall' shear stress plays marginal role. However, with particle diameter increases, the increment of $\tau_{P}$ is substantial. As an example, the 'particles-wall' shear stress at $\mathrm{d}_{P}=5 \mathrm{~mm}$, and $\mathrm{C}_{V}=20 \%$ is almost 25 times higher compared to $\mathrm{d}_{P}=1$ $\mathrm{mm}$ at the same $\mathrm{C}_{V}$, which Fig. 9a presents. The other parameter which plays a crucial role on the 'particles-wall' shear stress is solid concentration. Increasing solid concentration substantially increases the 'particles-wall' shear stress, which is seen in Fig. 9a-9c.

It is very interesting to compare the 'particles-wall' shear stress with the 'liquid-wall' shear stress at the pipe wall. The dependence of Reynolds number for carrier liquid phase $\left(\operatorname{Re}_{L}\right)$ on the shear stress of each phase, for few solids density, and few particle diameters, equal to: $\mathrm{d}_{P}=1,2.5$ and 5 $\mathrm{mm}$, at constant $\mathrm{C}_{V}=40 \%$ are shown in Fig. 10a-10c. Although the solid concentration is high $\left(\mathrm{C}_{V}=40 \%\right)$, the 'particles-wall' shear stress does not play significant role, compared to the 'liquid-wall' shear stress, if particle diameter is equal to $\mathrm{d}_{P}=1 \mathrm{~mm}$. The importance of the 'particles-wall' shear stress increases with particle diameter increase. If particle diameter is sufficiently high, the 'particles-wall' shear stress plays a crucial role compared to the 'liquid-wall' shear stress. As an example, the 'particles-wall' shear stress for $\mathrm{d}_{P}=5 \mathrm{~mm}$ and $\rho_{P}=3000 \mathrm{~kg} / \mathrm{m}^{3}$ is four times higher compared to the 'liquid-wall' shear stress, which Fig. 10c presents.

Fig. 11 shows the dependence of the solid particle diameter on the 'particles-wall' shear stress for some values of solid concentration and for constant bulk velocity equal to $\mathrm{U}_{S}=4.5 \mathrm{~m} / \mathrm{s}$ and for constant solid density equal to $\rho_{P}=1045 \mathrm{~kg} / \mathrm{m}^{3}$. It is evident that the influence of the particle diameter and the solid concentration on relation $\tau_{P}=\mathrm{f}\left(\mathrm{d}_{P}\right)$ is substantial. However, if solid concentration is equal to $20 \%$ by volume, the increase of $\tau_{P}$ is not so critical. This is consistent with the results of some researchers who emphasized that for solid concentration up to $20 \%$ by volume discrepancies between slurry flow and equivalent single-phase flow are almost linear, [1].

The dependence of the solid concentration on the 'particles-wall' shear stress for some values of particles diameter and for constant $\mathrm{U}_{S}$, and $\rho_{P}$ is presented in Fig. 12. As discussed above, particle diameter and solid concentration play substantial role in the 'particles-wall' shear stress, and taking them into account in any mathematical model to predict frictional head loss or abrasive process is mandatory. 

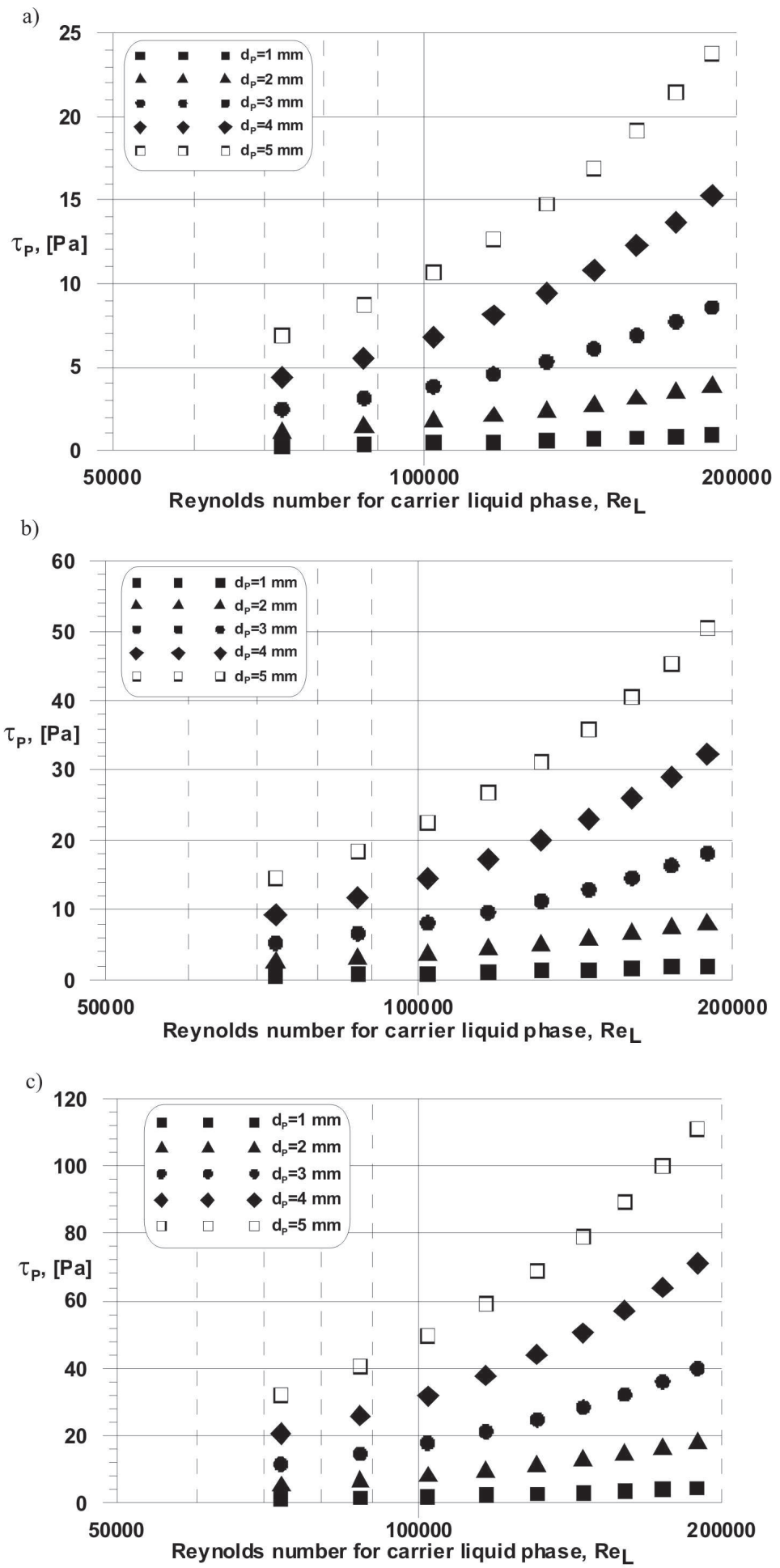

Fig. 9. Dependence of Reynolds number on the 'particles-wall' shear stress for: a) $\rho_{P}=1045 \mathrm{~kg} / \mathrm{m}^{3}, \mathbf{C}_{V}=\mathbf{2 0 \%}$ and for different ' $\mathrm{d}_{P}$ '; b) $\rho_{P}=1045 \mathrm{~kg} / \mathrm{m}^{3}, \mathbf{C}_{V}=\mathbf{3 0 \%}$ and for different ' $\mathrm{d}_{P}$ '; c) $\rho_{P}=1045 \mathrm{~kg} / \mathrm{m}^{3}, \mathbf{C}_{V}=\mathbf{4 0 \%}$ and for different ' $\mathrm{d}_{P}$ ' 

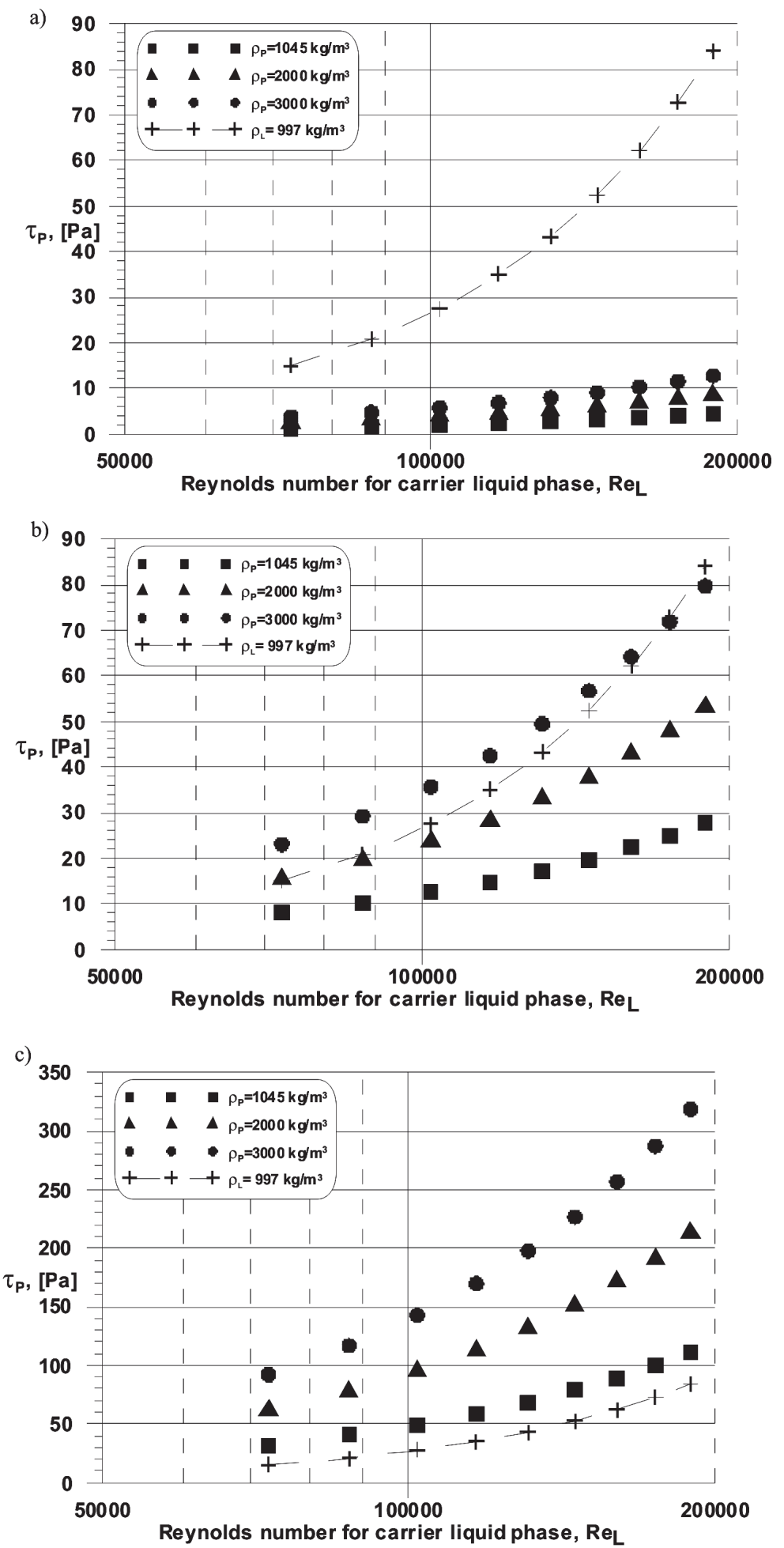

Fig. 10. Dependence of Reynolds number on the 'particles-wall' shear stress for: a) $\mathrm{C}_{V}=40 \%$,

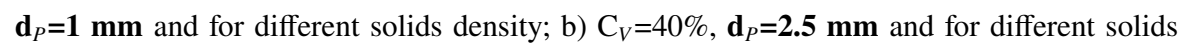
density; c) $\mathrm{C}_{V}=40 \%, \mathbf{d}_{P}=\mathbf{5} \mathbf{~ m m}$ and for different solids density 


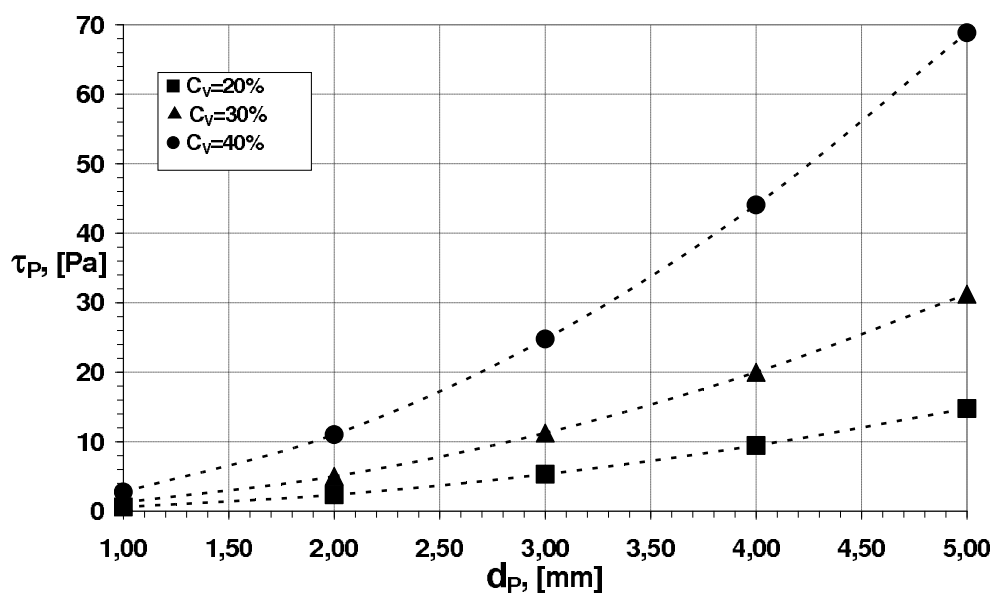

Fig. 11. Dependence of the solid particle diameter on the 'particles-wall' shear stress for $\mathrm{U}_{S}=4.5 \mathrm{~m} / \mathrm{s}, \rho_{P}=1045 \mathrm{~kg} / \mathrm{m}^{3}$ and for different $\mathrm{C}_{V}$

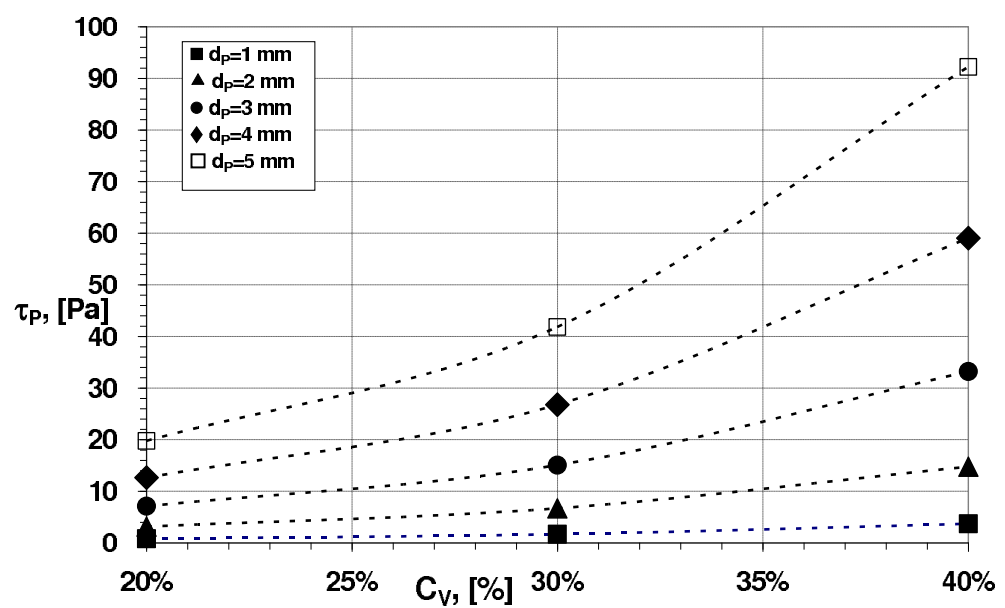

Fig. 12. Dependence of the solid concentration on the 'particles-wall' shear stress for $\mathrm{U}_{S}=4.5 \mathrm{~m} / \mathrm{s}, \rho_{P}=1400 \mathrm{~kg} / \mathrm{m}^{3}$ and for different ' $\mathrm{d}_{P}$ '

\section{Discussion}

In the paper, the author has focused on the influence of coarse-dispersive particles on the additional stress due to the 'particles-wall' interaction in solid-liquid turbulent flow with moderate and high solid concentration. Such an additional stress plays an important role when frictional head loss or abrasive process is taking into account.

The simulations were performed using mathematical model which assumes that the total shear stress at the pipe wall is a sum of the 'liquid-wall' 
and the 'particles-wall' stress [10], [26]. The 'particles-wall' shear stress was designated using Bagnold's concept, [15]. The phenomenological model allows predicting the 'particles-wall' shear stress, friction factor, and frictional head loss if the flow is fully developed, axially symmetrical and if all coarse particles are narrowly sized. The 'particles-wall' shear stress depends on several parameters, as the solid particle diameter, particle density, solid concentration, strain rate, maximum possible static solid concentration, and Reynolds number for carrier liquid phase.

The results of simulation show qualitative and quantitative dependence of particle diameter, particle density, and solid concentration on the 'particleswall' shear stress. It is evident that among the aforementioned parameters the solid particle diameter plays crucial role in its dependence on the "particleswall' shear stress. For some flow conditions, the 'particles-wall' stress is several times higher compared to the carrier liquid stress at the pipe wall, which is clearly shown in Fig. 10b and 10c. Another parameter which affects strongly the 'particles-wall' shear stress is the solid concentration. However, it should be pointed out that importance of the solid concentration takes place if the solid concentration is above $20 \%$ by volume. The influence of the solid particle density on the 'particles-wall' shear stress is important, but its meaning comparing to the particle diameter and the solid concentration is less significant.

As mentioned in chapter 1 , there are evidences in the literature that the solid concentration decreases towards the wall if the slurry flow with coarse particles is considered, [16] to [18]. That phenomena result from lift forces, which act from the wall toward the symmetry axis. These cause that contacts of solid particles with a pipe wall are not so intensive as we expect. Additionally, the presence of solid particles in a carrier liquid phase can increase or reduce the level of turbulence. Experiments of Schreck and Kleis proved that swirls, whose dimensions are lower compared to solid particle diameter, drastically reduce particles shade causing that the level of turbulence decreases, [20]. Unfortunately, there is no simple expression in literature which can resolve if there is an increase or damping of turbulence.

The mathematical model in its simplicity includes, through empirical function $\left(\mathrm{B}_{B}\right)$, the phenomena which are not directly included in the model, like for instance: slip velocity between the liquid and the solid phase, lift forces acting on solid particles in close vicinity of a pipe wall, and bursting phenomena. This causes that the mathematical model has some limitation, and is probably not suitable for predicting slurry flow with coarse particles lower than $1.5 \mathrm{~mm}$ and higher than $5 \mathrm{~mm}$. 


\section{NOMENCLATURE}

A $\quad-$ pipe cross section, $\left[\mathrm{m}^{2}\right]$

$\mathrm{A}_{B} \quad$ - function in equation for the 'particles-wall' shear stress

$\mathrm{B}_{B}-$ empirical function in equation for the 'particles-wall' shear stress, $\left[\mathrm{m}^{-2}\right]$

C - local volumetric concentration of solids, \%

$\mathrm{C}_{\max }-$ maximum possible static concentration by volume of solids in a pipe, [\%]

$\mathrm{C}_{V} \quad-$ averaged solid concentration (volume fraction of solids averaged in cross section), $\%$

$\mathrm{d}_{P} \quad-$ solid particle diameter, $[\mathrm{mm}]$

D $\quad$ - inner pipe diameter, [m]

g - gravitational acceleration, $\left[\mathrm{m} / \mathrm{s}^{2}\right]$

$\mathrm{h} \quad-$ elevation above datum, [m]

$\mathrm{i}_{L} \quad-$ carrier liquid frictional head loss, [m water / $\mathrm{m}$ pipe]

$\mathrm{i}_{m} \quad-$ slurry frictional head loss, [m water / $\mathrm{m}$ pipe]

$\mathrm{K}$ - proportionality coefficient in Bagnold's equation

$\mathrm{N}_{B} \quad-$ dimensionless Bagnold's number

$\mathrm{p} \quad-$ static pressure, $[\mathrm{Pa}]$

$\mathrm{p}^{*} \quad-$ static pressure in vertical pipe flow due to gravity, $[\mathrm{Pa}]$

$\mathrm{r} \quad-$ distance from symmetry axis, [m]

$\mathrm{R} \quad-$ pipe radius, $[\mathrm{m}]$

$\operatorname{Re}_{L} \quad-$ Reynolds number for carrier liquid phase, $\operatorname{Re}_{L}=\rho_{L} \mathrm{U}_{S} \mathrm{D} / \mu_{L}$

$\mathrm{S} \quad$ - ratio of the solid phase density to the liquid phase density

$\mathrm{T} \quad-$ temperature, $[\mathrm{K}]$

$\vec{U} \quad-\quad$ velocity vector, $\vec{U}=\vec{i} U+\vec{j} V+\vec{k} W,[\mathrm{~m} / \mathrm{s}]$

$\mathrm{U}$ - velocity component in the main flow direction 'ox', $[\mathrm{m} / \mathrm{s}]$

$\mathrm{V}$ - velocity component in 'oy' direction, $[\mathrm{m} / \mathrm{s}]$

$\mathrm{W}$ - velocity component in 'oz' direction, [m/s]

$\mathrm{U}_{S} \quad$ - velocity averaged over a pipe cross section, $[\mathrm{m} / \mathrm{s}]$

$\mathrm{x} \quad-$ coordinate for 'ox' direction, $[\mathrm{m}]$

y $\quad-$ distance from a pipe wall, [m] 


\section{Greek Symbols}

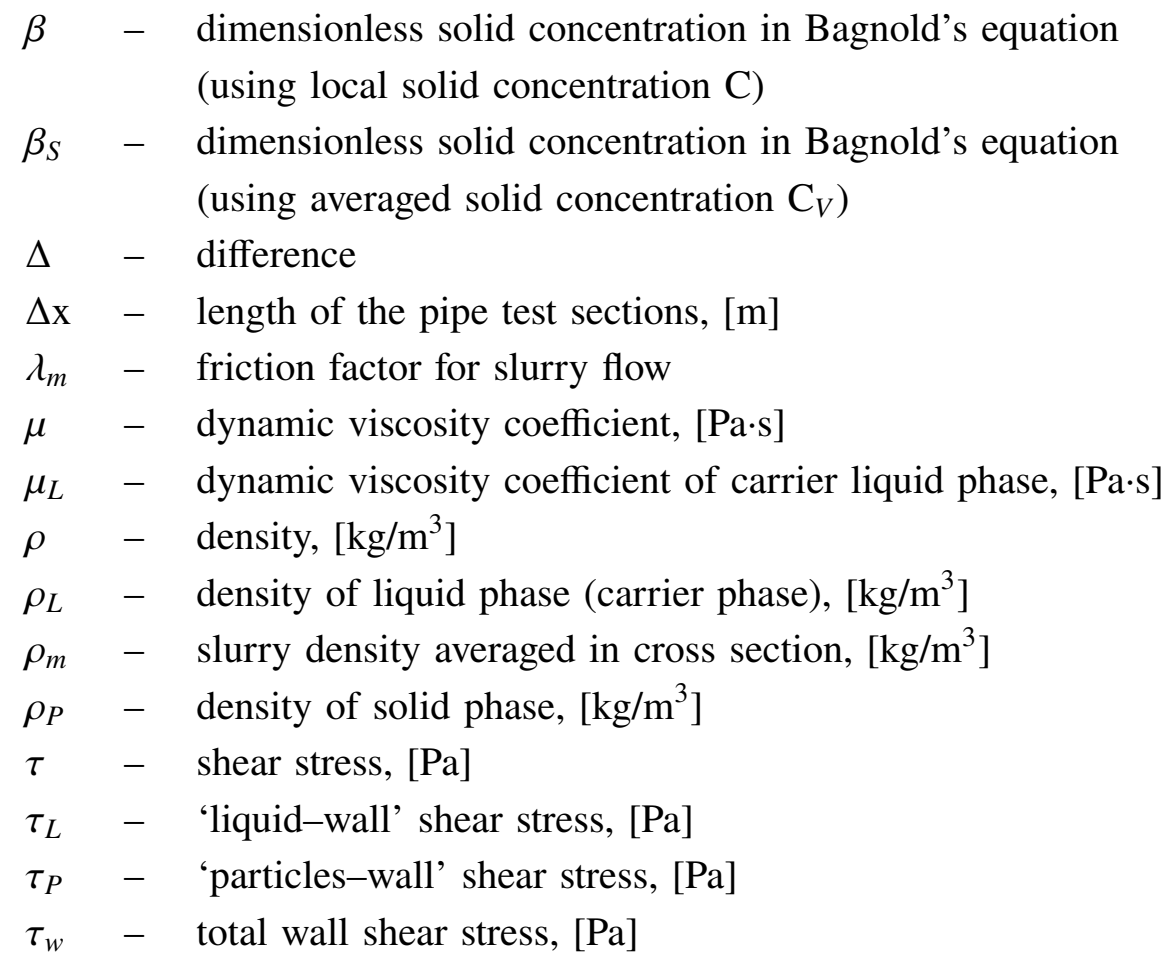

\section{Indexes}

L - liquid phase

$\mathrm{m}$ - value for slurry (solid-liquid mixture, hydro-mixture)

$\mathrm{P} \quad$ - solid particle (solid phase)

$\mathrm{S} \quad-\quad$ averaged in cross-section (bulk)

$\mathrm{V} \quad-$ volumetric,

$\mathrm{w}-$ pipe wall

Manuscript received by Editorial Board, December 02, 2009; final version, March 10, 2010.

\section{REFERENCES}

[1] Wilson K.C., Addie G.R., Sellgren A., Cliff R.: Slurry transport using centrifugal pumps. Springer Science, 2006. 
[2] Shook C.A., Roco M.C.: Slurry Flow: Principles and practice. Boston, ButterworthHeinemann, 1991.

[3] Bartosik, A.: Laminarisation effect in fine-dispersive slurry flow. Archives of Thermodynamics, 2008, vol. 29, No. 3, pp. 69-82.

[4] Bartosik A.: Application of rheological models in prediction of turbulent slurry flow. Flow, Turbulence and Combustion, Springer-Verlag, 2009, vol. 84, No. 2, pp. 277-293.

[5] Doron P., Barnea D.: Flow pattern maps for solid liquid flow in pipes. Int. J. Multiphase Flow, 1996, vol. 22, pp. 273-283.

[6] Televantos Y., Shook C.A., Carleton A.: Street, M.: Flow of slurries of coarse particles at high solid concentration. Can. J. Chem. Eng., 1979, vol. 57, pp. 255-262.

[7] Wasp E.J., Kenny J.P., Gandhi R.L.: Solid-liquid flow slurry pipeline transportation. Ser. on Bulk Materials Handling, Trans. Tech. Publications, Germany, 1999.

[8] Gillies R.G., Shook C.A., Wilson K.C.: An improved two-layer model for horizontal slurry pipeline flow. Can. J. Chemical Engng., 1991, vol. 69, pp. 173-178.

[9] Gillies R.G., Shook C.A., Xu J.H.: Modelling heterogeneous slurry flows at high velocities. Can. J. Chemical Engng., 2004, vol. 82, No. 5, pp. 1060-1065.

[10] Bartosik A.: Modelling the Bagnold stress effects in vertical slurry flow. J. Hydrology and Hydromechanics, 1996, vol. 44, No. 1, pp. 48-57.

[11] Bartosik A.: Modification of $\mathrm{k}-\varepsilon$ model for slurry flow with the yield stress, Proc. 10th Int. Conf. Numerical Methods in Laminar and Turbulent Flow. Editors: C.Taylor, J.T. Cross, Pineridge Press, UK., 1997, vol. 10, pp. 265-274.

[12] Mishra R., Singh S.N., Seshadri V.: Improved model for the prediction of pressure drop and velocity field in multi-sized particulate slurry flow through horizontal pipes. Powder Handling Processing, 1998, vol. 10, No. 3, pp. 279-287.

[13] Wilson K.C., Thomas A.D.: Analytic model of laminar-turbulent transition for Bingham plastics. Canadian J. Chem. Eng., 2006, vol. 84, No. 5, pp. 520-526.

[14] Talmon A.M.: Boundary layer theory for solid-liquid mixtures tested against Couette flow. Proceed. 14th Int. Conf. Transport and Sedimentation of Solid Particles, 23-27 June, 2008, St. Petersburg, pp. 293-300.

[15] Bagnold R.A.: Experiments on a gravity-free dispersion of large solids spheres in a Newtonian fluid under shear. Proc. Roy. Soc., 1954, vol. 225, Ser. A, pp. 49-63.

[16] Nasr-El-Din H., Shook C.A., Colwell J.: A conductivity probe for measuring local concentrations in slurry systems. Int. J. Multiphase Flow, 1987, vol. 13, pp. 365-378.

[17] Sumner R.J., McKibben M., Shook C.A.: Concentration and velocity distribution in turbulent vertical slurry flow. J. Solid Liquid Flow, 1991, vol. 2, No. 2, pp. 33-42.

[18] Eskin D., Miller M.J.: A model of non-Newtonian slurry flow in a fracture. Powder Technology, 2008, vol. 182, pp. 313-322.

[19] Kuboi R., Komasawa I., Otake T.: Fluid and particle motion in turbulent dispersion-II influence of turbulence of liquid on the motion of suspended particles. Chem. Eng. Sci., 1974, vol. 29, pp. 651-657.

[20] Schreck S., Kleis S.J.: Modification of grid-generated turbulence by solid particles, J. Fluid Mech., 1993, vol. 249, pp. 665-688.

[21] Nouri J.M., Whitelaw J.H.: Particle velocity characteristics of dilute to moderately dense suspension flows in stirred reactors. Int. J. Multiphase Flow, 1992, vol. 18, No. 1, pp. 21-33.

[22] Chen R.C., Kadambi J.R.: Discrimination between solid and liquid velocities in slurry flow using Doppler Velocimeter. ASME, Powder Technology, 1995, vol. 85, pp. 127-134.

[23] Gore R.A., Crowe C.T.: Modulation of turbulence by a dispersed phase. ASM, J. Fluid Engng., 1991, vol. 113, pp. 304-307.

[24] Fessler J.R., Eaton J.K.: Turbulence modification by particles in a backward-facing step flow. J. Fluid Mech., 1999, vol. 394, pp. 97-117. 
[25] Sundaresan S., Eaton J., Koch D.L., Ottino J.M.: Appendix 2: Report of study group on disperse flow. Int. J. Multiphase Flow, 2003, vol. 29, pp.1069-1087.

[26] Shook C., Bartosik A.: Particle-wall stresses in vertical slurry flows. Powder Technology, Elsevier Science, 1994, vol. 81, pp. 117-124.

[27] Longwell P.A.: Mechanics of fluid flow. New York: Mc Graw-Hill, 1966.

[28] Matousek V.: Pressure drop and flow patterns in sand-mixture pipes. Experimental, Thermal and Fluid Science, 2002, vol. 26, pp. 693-702.

[29] Bartosik A.: Badania symulacyjne i eksperymentalne osiowo-symetrycznego przepływu drobno- i grubodyspersyjnej hydromieszaniny w przewodach tłocznych, Monografia M-11, Politechnika Świętokrzyska, Kielce, 2009.

Wpływ grubodyspersyjnej fazy stałej na naprężenie styczne 'cząstki - ściana' w turbulentnym przepływie hydromieszaniny dla wysokich koncentracji fazy stałej

\section{Streszczenie}

Artykuł dotyczy symulacji w pełni rozwiniętego, osiowo-symetrycznego przepływu turbulentnego grubodyspersyjnej hydromieszaniny z cząstkami stałymi o podobnym wymiarze i kształcie, o średnicy od $1[\mathrm{~mm}]$ do $5[\mathrm{~mm}]$, gęstości cząstek od $1045\left[\mathrm{~kg} / \mathrm{m}^{3}\right]$ do $3000\left[\mathrm{~kg} / \mathrm{m}^{3}\right]$ i objętościowej koncentracji fazy stałej od $20 \%$ do $40 \%$. W pracy zbadano wpływ średnicy cząstek stałych na dodatkowe naprężenia styczne w przepływającej hydromieszaninie będące wynikiem interakcji 'cząstki stałe-ściana' dla umiarkowanych i wysokich koncentracji fazy stałej. Model matematyczny powstał na bazie koncepcji Bagnolda, [26] i zakłada, że całkowite naprężenie styczne na ściance przewodu równe jest sumie naprężenia 'ciecz-ściana' i 'cząstki stałe-ściana'. Model matematyczny pozwala na przewidywanie: naprężeń stycznych 'cząstki stałe-ściana', spadku ciśnienia oraz współczynnika strat tarcia w turbulentnym przepływie grubodyspersyjnej hydromieszaniny, [10]. Model matematyczny pozytywnie zweryfikowano $\mathrm{z}$ wynikami własnych badań eksperymentalnych dla grubodyspersyjnej hydromieszaniny typu: 'piasek-woda', 'polistyren-woda' i 'pvc-woda'.

Wyniki symulacji przedstawiają jakościową i ilościową zależność naprężeń stycznych 'cząstki stałe-ściana' od średnicy cząstki stałej, gęstości cząstki stałej, objętościowej koncentracji fazy stałej i liczby Reynoldsa dla fazy nośnej. Wykazano, że średnica cząstek stałych ma zasadniczy wpływ na naprężenie styczne 'cząstki stałe-ściana'. Wykazano także, że dla określonych warunków przepływu naprężenie styczne 'cząstki stałe-ściana' znacznie przewyższa naprężenie styczne 'faza nośnaściana'. 